\title{
Penerapan Konsep Superblok dalam Perancangan Kawasan TERPADU Di JALUR LingKar UTARA Kota SURAKarta
}

\author{
VALENTINUS BORIS ${ }^{1}$ \\ PROGRAM STUDI ARSITEKTUR \\ FAKULTAS TEKNIK \\ UNIVERSITAS SEBELAS MARET, SURAKARTA \\ email : valentinusboris@yahoo.com \\ IR. SAMSUDI, M.T. ${ }^{2}$ \\ PROGRAM STUDI ARSITEKTUR \\ FAKULTAS TEKNIK \\ UNIVERSITAS SEBELAS MARET, SURAKARTA \\ IR. AGUNG KUMORO W.W., M.T. ${ }^{3}$ \\ PROGRAM STUDI ARSITEKTUR \\ FAKULTAS TEKNIK \\ UNIVERSITAS SEBELAS MARET, SURAKARTA
}

\begin{abstract}
The number of population in cities has increased into a very spectacular number. That phenomenon simultaneously pushes the cities to find the solutions that could comprehensively solve many urban problems. Especially in the developing cities, the problems are much complexier. Inefficient urban planning is the main problem which is derived into such problems: traffic jam; backlog increasing number; floods; etc. One that could be the solution is the superblock concept. Superblock could provide an integrative planning between many function zones: residencials; offices; shopping center; public spaces; etc. In this concept, citizens could do their daily activities just in one site because all places are closely connected. City of Surakarta is one of developing cities in Indonesia which has many urban problems and potentials. High population density, backlog number, and traffic jam are the problems. On the other hand, the city also has potentials: high public economic level, high property commercial market, and developments of the city. By those problems and potentials, City of Surakarta could adapt the superblock concept to develops a mixed-use area. Mixed-use area could solve the vital problems: backlog number. By the superblock concept, the mixed-use area can not only provide residencial facilities but also can provide commercial areas to develop the city such as shopping center and retail offices for the inhabitant's lifestyle fulfillment. 2500 units apartment, 250 units retail office, shopping center, and public park are the main facilities in this mixed-use area. Each facility is also devided into some supporting facilities. By adapting the concept of superblock in planning a mixed-use area, several of urban problems in the City of Surakarta are hopefully solved.
\end{abstract}

Keywords: Population, Cities, Superblock, Mixed-Use, Surakarta

\section{PENDAHULUAN}

Kota adalah segalanya tentang sistem peradaban manusia yang kompleks. Peradaban tinggi manusia di kota membuat semakin banyak orang yang tertarik hidup di kota. Namun, kota semakin menemui masalah-masalah yang mengancam keberlangsungannya. Peningkatan kepadatan penduduk di kota menjadi masalah paling rumit karena menyangkut semua aspek berjalannya sebuah kota. Menurut proyeksi KSPPN (Kebijakan dan Strategi 
Pembangunan Perkotaan Nasional) tahun 2003 menyebutkan bahwa, pada tahun 2050 85\% penduduk Indonesia akan tinggal di kota. Peningkatan jumlah penduduk kota menghasilkan beberapa persoalan integral. Kebutuhan hunian di Indonesia semakin meningkat. Menurut Direktur Jenderal Pembiayaan Perumahan Kementerian PUPR, Maurin Sitorus (2016), hingga tahun 2025 angka kebutuhan rumah di Indonesia mencapai 30 juta unit.

Masalah-masalah perkotaan yang semakin kompleks menuntut konsep dan strategi perancangan yang responsif terhadap perubahan dan mampu mengontrol pertumbuhan kota. Menurut Wibisono (2010), salah satu konsep yang berkembang adalah menciptakan zonazona terkontrol. Konsep ini sudah diterapkan di Eropa dan Amerika Serikat di tahun 1920-an dengan berbagai istilah. Salah satunya adalah konsep Superblok.

Salah satu kota yang memiliki permasalahan perkotaan adalah Kota Surakarta. Kota Surakarta menarik untuk dikembangkan konsep superblok karena memiliki masalah-masalah perkotaan yang kompleks, pasar properti yang meningkat dan didukung pembangunan fisik di dalam kota. Kepadatan penduduk Kota Surakarta mencapai 11.582 jiwa $/ \mathrm{km}^{2}$. Angka tersebut masih belum ditambah populasi penduduk daerah sekitar yang rutin beraktivitas di Kota Surakarta. Menurut Walikota Kota Surakarta, F.X. Hadi Rudyatmo (2014), populasi penduduk siang hari Kota Surakarta mencapai tiga juta jiwa, sedangkan populasi penduduk Kota Surakarta sekitar lima ratus ribu jiwa.

Banyaknya penduduk daerah lain yang rutin menglaju ke Kota Surakarta mengakibatkan meningkatnya jumlah kendaraan pribadi yang berujung pada masalah kemacetan dan polusi udara yang tinggi. Menurut Kepala Dinas Perhubungan, Komunikasi, dan Informatika (Dishubkominfo) Kota Surakarta, Yosca Herman Sudrajat (2015), menyebutkan bahwa jumlah kendaraan bermotor berplat Kota Surakarta mencapai 470.000 kendaraan. Jika dibandingkan dengan jumlah penduduk Kota Surakarta yang berjumlah 510.077 jiwa, berarti hampir setiap penduduk memiliki satu kendaraan pribadi. Belum lagi ditambah 2,5 juta penduduk penglaju ke Kota Surakarta yang kemungkinan besar juga memakai kendaraan pribadi, berarti ada tiga juta kendaraan pribadi di Kota Surakarta tiap harinya.

Tingginya aktivitas di Kota Surakarta dan sekitarnya membuat kebutuhan hunian menjadi sangat tinggi. Menurut Ketua Dewan Pengurus Daerah (DPD) Real Estat Indonesia (REI) Jateng, M.R. Priyanto (2014), khusus di Kota Surakarta, terjadi backlog (angka kekurangan hunian) mencapai 45.242 unit.

Kota Surakarta dengan berbagai masalah dan potensi kota yang dimiliki dapat mengadaptasi sistem superblok untuk membentuk kawasan terpadu. Kawasan terpadu diperlukan sebagai usaha mengefisienkan tata ruang kota dengan memadukan fungsi residensial dengan fungsi-fungsi lain seperti tempat bekerja dan rekreasi. Dengan konsep superblok, kawasan terpadu yang dirancang dapat lebih berkembang dan meningkatkan kualitas ruang kota.

\section{METODE}

Metode yang dilakukan dalam perancangan kawasan terpadu di Jalur Lingkar Utara Kota Surakarta ini adalah dengan mengolah desain kawasan terpadu berlandaskan prinsip-prinsip utama dalam konsep superblok sehingga menghasilkan desain akhir menjadi solusi atas isu dan fenomena serta permasalahan dan persoalan dalam kawasan terpadu.

Menurut Ir. Manlian Ronald A. Simanjuntak, M.T., IAI (2004), secara umum superblok dapat diartikan sebagai suatu kawasan binaan atau terpadu yang terdiri dari fungsi-fungsi seperti pusat perbelanjaan, area perkantoran, hunian (apartemen), hotel, sarana rekreasi, dan area terbuka, yang kesemuanya memiliki 
hubungan dan saling menunjang dalam fungsi dan kegiatan.

Dalam pidato Prof. Ir. Bambang Hari Wibisono, MUP., M.Sc., Ph.D tahun 2010, mengatakan bahwa konsep superblok bisa berkembang dan direspon positif oleh masyarakat luas apabila dalam perancangan superblok memiliki lima konsep utama dari proses perencanaan hingga menjadi produk yang siap dipasarkan, antara lain:

A. Identity/Branding

Merupakan pendekatan studi kelayakan dan studi konsep identitas ekonomi. Banyaknya produk properti yang beridentitas menarik dan bernilai tinggi menyebabkan kawasan superblok harus memiliki identitas yang tematik. Dengan identitas ini maka kawasan superblok memiliki posisi pasar yang kuat dan berbeda dengan posisi pasar kawasan-kawasan lainnya.

\section{B. Mix of Uses}

Merupakan konsep tata guna lahan yang bersifat campuran, di mana elemen fungsi hunian, publik, komersial, dan rekreasi bisa hadir dalam satu kawasan. Selain itu, sistem peruntukan lantai dasar haruslah digunakan untuk kegiatan ritel atau fungsi publik aktif yang secara fisik transparan untuk menjamin hadirnya aktivitas publik dari pagi sampai malam.

\section{Massing Framework}

Merupakan kepekaan rancangan akan konteks urban. Konsep "streetwall” di mana deretan bangunan lurus sejajar mendefinisikan ruang jalan disarankan dikombinasikan dengan penggunaan ruang di zona garis sempadan bangunan (GSB) sebagai jalur publik aktif. Satu bangunan tertinggi atau terunik biasanya diperlukan sebagai tengaran (landmark) yang dikelilingi oleh bangunan yang karakternya tidak terlalu menonjol (background building).

\section{Efficient Vehicular Circulation \\ Merupakan konsep sirkulasi kendaraan yang dirancang seefisien mungkin. Strategi manajemen lalu lintas}

dalam superblok adalah dengan menyediakan transportasi publik internal area yang terhubung dengan jaringan transportasi publik kota. Konsep drop off untuk kendaraan dan parkir di lantai dasar depan gedung sebaiknya juga dikurangi. Konsep basement yang terkoneksi satu dengan yang lain menjadi inovasi dalam konteks manajemen lalu lintas kawasan superblok.

\section{E. Multilayers Pedestrian Linkage \\ Merupakan pengembangan} kawasan yang aman dan nyaman bagi pejalan kaki. Selain fasilitas pejalan kaki di lantai dasar, konsep area pejalan kaki dapat dikembangkan pula di lantai berikutnya dengan kemungkinan menembus massa-massa bangunan yang berada di kawasan tersebut.

Kawasan terpadu yang dirancang penulis akan menerapkan kelima prinsip utama superblok tersebut agar didapatkan hasil akhir rancangan yang sesuai.

\section{PEMBAHASAN}

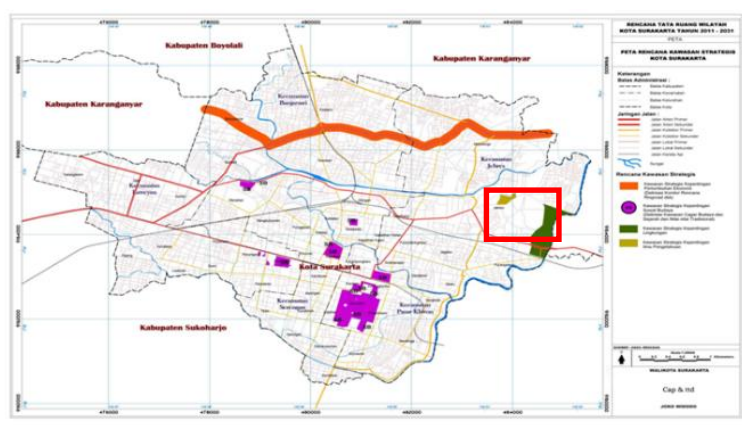

Gambar 1. Rencana Tata Ruang Wilayah Kota Surakarta Tahun 2011-2031. Kawasan jalur lingkar utara (dalam kotak merah garis oranye) merupakan kawasan Strategis Kepentingan Pertumbuhan Ekonomi. Sumber: PERDA Kota Surakarta Nomor 1 Tahun 2012 Tentang Rencana Tata Ruang Wilayah Kota Surakarta Tahun 2011-2031.

Kawasan terpadu ini akan berlokasi di jalur lingkar utara yang berada di wilayah administratif Kota Surakarta. 
Wilayah ini masuk dalam wilayah Kelurahan Mojosongo Kecamatan Jebres.

Dalam Peta Rencana Tata Ruang Wilayah Kota Surakarta Tahun 2011-2031, wilayah Kota Surakarta bagian utara (wilayah-wilayah di sekitar garis oranye) diarakan menjadi Kawasan Strategis Kepentingan Pertumbuhan Ekonomi (Delinasi Koridor Rencana Ringroad dsk). Hal ini menunjukan masih potensialnya Kota Surakarta dalam perkembangan ekonominya, termasuk di bidang properti, khususnya di kawasan ringroad utara yang masih memiliki banyak potensi lahan kosong. Jalur lingkar utara merupakan salah satu area Kota Surakarta bagian utara yang akan dikembangkan menjadi kawasan bisnis baru.

Selain sebagai kawasan bisnis, Kecamatan Jebres juga masuk sebagai wilayah yang direncanakan sebagai kawasan peruntukan perumahan dengan bangunan vertikal berupa rumah susun atau apartemen (PERDA Kota Surakarta Nomor 1 Tahun 2012 Tentang Rencana Tata Ruang Wilayah Kota Surakarta Tahun 2011-2031 pasal 71). Hal ini karena Kecamatan Jebres masuk dalam kawasan pemukiman berkepadatan tinggi (pasal 43 ayat 4$)$.

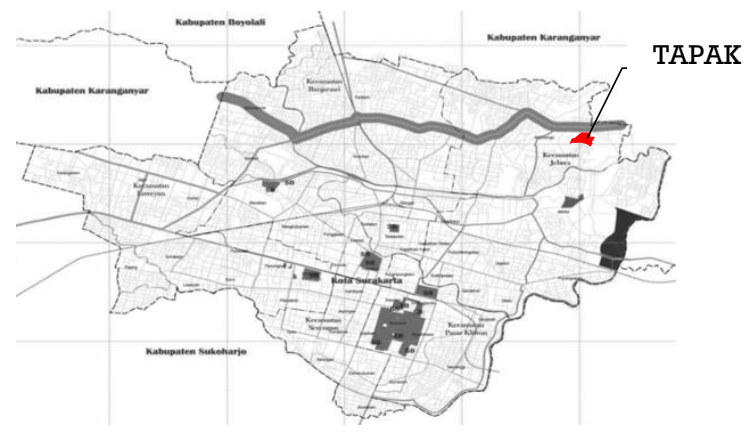

Gambar 2. Lokasi Tapak Kawasan Terpadu Terpilih.

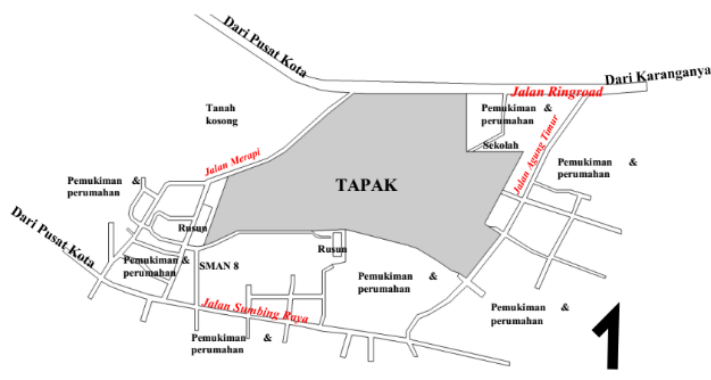

Gambar 3. Tapak

Kawasan Terpadu Terpilih.

Tapak yang akan dipilih adalah pilihan tapak 3 karena memiliki luas besar yaitu 18,4 ha, dikelilingi banyak jalan di sekitarnya yaitu Jalan Ringroad (Jalur Lingkar Utara) sebagai jalan utama dna Jalan Merapi dan Jalan Agung Timur sebagai jalan alternatif dari pemukiman sekitar. Tapak ini juga dekat dengan fasilitas publik sekitar tanpa harus menyeberang jalan seperti Institut Seni Indonesia (ISI) Surakarta dan Universitas Sebelas Maret (UNS). Tapak juga tidak berdekatan dan tidak terimbas dengan Tempat Pembuangan Akhir (TPA) Putri Cempo yang ada di utara Jalur Lingkar Utara.

Kawasan terpadu yang dirancang di Jalur Lingkar Utara Kota Surakarta ini menerapkan konsep superblok yang terdiri dari lima prinsip utama. Penerapan prinsip-prinsip tersebut adalah sebagai berikut:

\subsection{Identity/ Branding}

Kebutuhan hunian yang sangat tinggi memiliki kecenderungan terbentuknya area hunian yang terlalu padat dan kualitas visual dan rasa lingkungan yang kurang nyaman. Selain itu, bangunanbangunan penunjang lainnya juga turut memberikan pengaruh visual dan pemanfaatan lahan. Bangunan tinggi memiliki efek visual yang sangat terasa tidak hanya dalam hal positif seperti membentuk citra kawasan dan kota yang dinamis tetapi juga hal negatif seperti rasa terkurung yang tidak nyaman. 


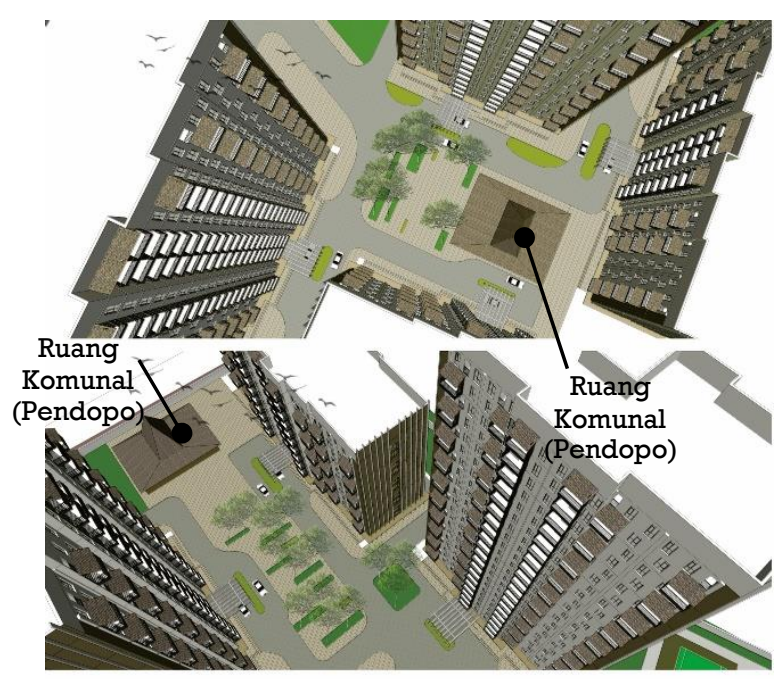

Gambar 1. Prinsip Identitas pada Zona Residensial.

Kawasan terpadu ini hadir di Kota Surakarta yang memiliki identitas budaya yang kuat khususnya berupa arsitektur Jawa yang sangat berkembang. Hadirnya identitas tersebut tidak hanya dapat membentuk karakter superblok dan Kota Surakarta tetapi juga dapat menjadi potensi pasar yang berbeda bagi superblok.

Prinsip identitas yang diterapkan di zona residensial berupa penggunaan atap yang tidak hanya sebagai elemen visual tetapi juga elemen fungsional. Selain itu terdapat pendopo-pendopo berapat limasan di antara bangunanbangunan apartemen sebagai ruang publik penghuni apartemen. Posisinya yang berada di tengah antar bangunan membuat pendopo lebih mudah terlihat sehingga citra kawasan terpadu dapat terasa lebih khas. Identitas kelokalan ini dapat menjadi pembentuk karakter kawasan terpadu yang lebih sesuai dengan Kota Surakarta.

Pada setiap unit apartemen dihadirkan atap tritisan sederhana sebagai atap balkon yang menjorok ke luar massa bangunan. Dengan material yang sama, bangunan apartemen akan terlihat senada dengan bangunanbangunan sekitarnya di kawasan terpadu ini walaupun memiliki massa yang besar dan tinggi. Repetisi permainan atap tritisan dan bukaan ini akan membentuk suatu ritme masing-masing bangunan. Permainan elemen atap tritisan pada setiap level bangunan sehingga membentuk bangunan modern yang tetap memperhatikan klimatologi seperti halnya bangunan arsitektur Jawa. Perpaduan warna atap hitam seperti sirap dengan cat tembok putih gading dapat membentuk rasa ruang yang kontekstual dengan Kota Surakarta sekaligus rasa ruang yang lebih lapang.

Penerapan bukaan berupa jendela sebagai ekspresi keterbukaan namun tetap privat bagi penghuni. Bukaan jendela akan dipadukan dengan balkon sehingga memungkinkan terjadinya komunikasi antar penghuni dari antar level maupun antar bangunan apartemen.

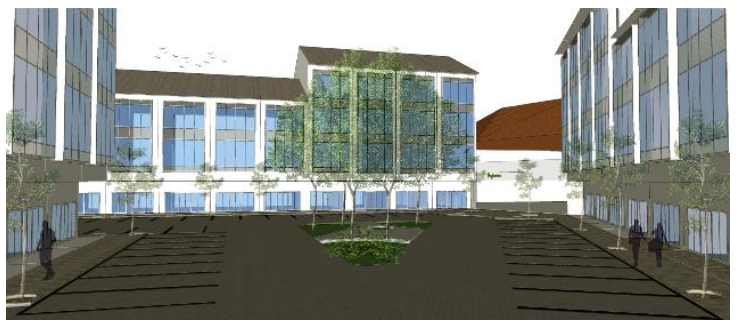

Gambar 2. Prinsip Identitas pada Zona Kantor Ritel.

Fasilitas kantor ritel juga dapat memiliki keselarasan karakter dengan bangunan-bangunan di zona komplek residensial untuk memperkuat kekhasan kawasan terpadu di Kota Surakarta. Bentuk bangunan-bangunan di zona kantor ritel menggunakan bentuk balok karena dapat mewadahi kebutuhan ruang dan pemanfaatan lahan dengan lebih efisien serta membentuk sistem utilitas yang lebih sederhana. Selain itu, bentuk bangunan-bangunan di zona ini juga menggunakan atap pelana untuk membentuk karakter kawasan terpadu yang lebih sesuai dengan karakter Kota Surakarta.

Bangunan kantor ritel menggunakan penutup bangunan berupa kombinasi tembok dan kaca sebagai pembungkus bangunan. Tembok putih gading dan 
kaca transparan biru dapat membentuk tampilan bangunan yang sederhana namun tetap modern dan fleksibel apabila akan ditambahi elemen khas perusahaan.

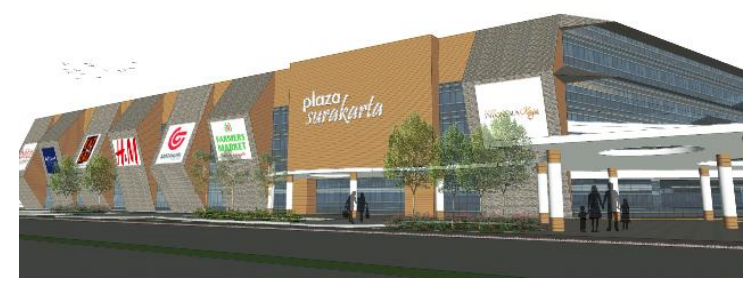

Gambar 3. Prinsip Identitas pada Zona Area Perbelanjaan.

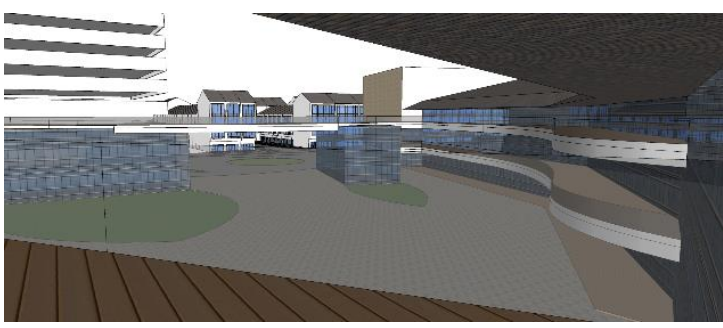

Gambar 4. Atap pada Keseluruhan Bangunan Shopping Mall.

Zona area perbelanjaan merupakan zona penyambut yang lokasinya paling depan berdekatan dengan Jalan Ringroad sehingga harus menjadi ikon utama dalam superblok. Karakter yang selaras dengan bangunan-bangunan di zona komplek residensial dan zona komplek perkantoran akan menguatkan kesan kawasan terpadu yang hadir di Kota Surakarta.

Bangunan shopping mall menerapkan karakter area perbelanjaan semi terbuka untuk membentuk rasa ruang shopping mall yang berbeda. Bentuk lengkung yang diterapkan bangunan shopping mall tidak akan ditutupi fasad lain namun akan langsung menampilkan ritel-ritel yang ada. Penyeragaman karakter lebih diterapkan pada karakter lanskap dan material bangunan.

Material bangunan yang digunakan lebih menonjolkan karakter kayu,bata merah, kerawang, dan tembok dengan warna putih gading. Hal ini untuk menguatkan karakter kawasan terpadu yang sesuai dengan konteks Kota Surakarta sehingga mendapatkan pasar yang sesuai pula.

Kesesuaian pemakaian material, bentuk, tampilan, dan elemen arsitektur pada setiap zona dapat membentuk identitas khusus pada kawasan terpadu yang berlokasi di Kota Surakarta. Karakter ini dapat pula membentuk kawasan sekitar Jalan Ringroad Kota Surakarta menjadi lebih hidup dan khas.

\subsection{Penerapan Prinsip Mix of Uses}

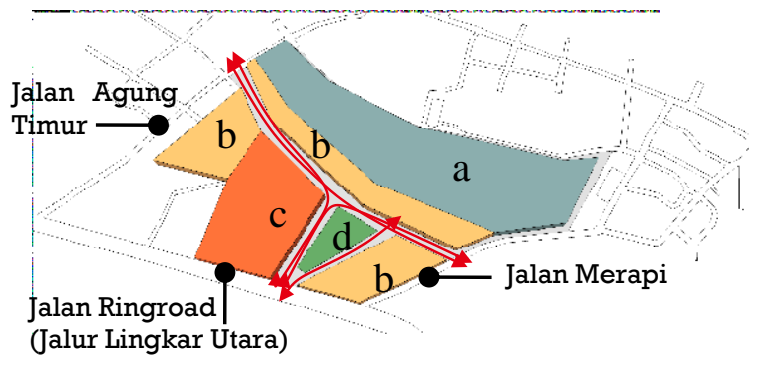

Gambar 1. Penzonaan Kawasan Terpadu.

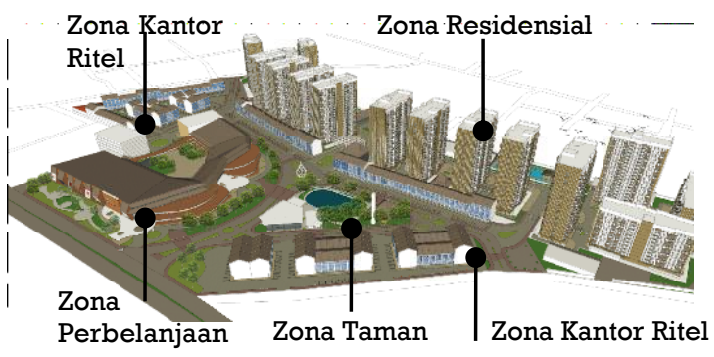

Gambar 3.2-2. Zona-Zona Di Kawasan Terpadu.

Kawasan terpadu di Jalur Lingkar Utara Kota Surakarta harus memenuhi kriteria sebagai potensi pengembangan properti dan salah satu solusi perkotaan di Kota Surakarta. Oleh karena itu, fungsi hunian, fungsi tempat bekerja, dan fungsi tempat berbelanja dan rekreasi harus terpenuhi. Fasilitas hunian berupa apartemen harus menyesuaikan kebutuhan yang sesuai dengan masyarakat di Kota Surakarta. Untuk memenuhi aspek kebutuhan hidup sehari-hari, diperlukan fasilitas tempat bekerja berupa kantor ritel dan tempat berbelanja berupa shopping mall. 
Prinsip percampuran fungsi dalam kawasan terpadu ini diterapkan dengan menata tiga fungsi utama (residensial, perkantoran, dan area perbelanjaan) ke dalam satu area tapak. Penataan zona menyesuaikan kebutuhan dari masingmasing zona agar setiap fungsi dapat berkembang dan saling mendukung.

Area (a) paling selatan menjadi zona residensial karena dapat mewadahi fasilitas hunian apartemen yang nyaman. Area (a) terpisah dengan area lainnya untuk memberikan aspek privasi dan kenyamanan penghuni dari kebisingan yang dihasilkan dari Jalan Ringroad dan area komersial lainnya. Di antara zona residensial dan titik pusat keramaian kawasan terpadu juga dapat diletakkan fasilitas dengan kebisingan rendah. Zona residensial diperkirakan menghasilkan kebisingan sedang bagi pemukiman dan perumahan di sekitar tapak.

Area (b) dekat dengan jalan sekitar tapak dan jalan sirkulasi dalam tapak sehingga dijadikan sebagai zona kantor ritel. Kantor ritel merupakan fasilitas yang juga membutuhkan kenyamanan kebisingan namun dapat disikapi dengan strategi desain apabila berada di dekat Jalan Ringroad. Fasilitas kantor ritel juga tidak menghasilkan kebisingan tinggi bagi zona residensial dan pemukiman dan perumahan di sekitar tapak.

Area (c) paling depan dan mudah terlihat dari jalan utama sehingga dapat dijadikan sebagai zona perbelanjaan berupa shopping mall. Shopping mall dapat menjadi penarik pengunjung dan meningkatkan pasar komersial kawasan terpadu. Zona perbelanjaan tidak begitu butuh kenyamanan kebisingan karena aktivitasnya bersifat rekreatif. Namun, shopping mall cenderung menghasilkan kebisingan tinggi bagi pemukiman dan perumahan di sekitar tapak sehingga butuh direduksi dengan fasilitas dengan kebisingan rendah antara shopping mall dengan zona residensial dan pemukiman dan perumahan di sekitar tapak.

Area (d) sebagai perantara antara berbagai zona dapat dijadikan area hijau dan penyerapan air hujan sehingga dapat menyegarkan dan menyeimbangkan kualitas ruang dalam tapak. Area ini dapat menjadi sarana taman dan kolam retensi yang rekreatif untuk pengguna kawasan terpadu.

\subsection{Penerapan Prinsip Massing Framework}

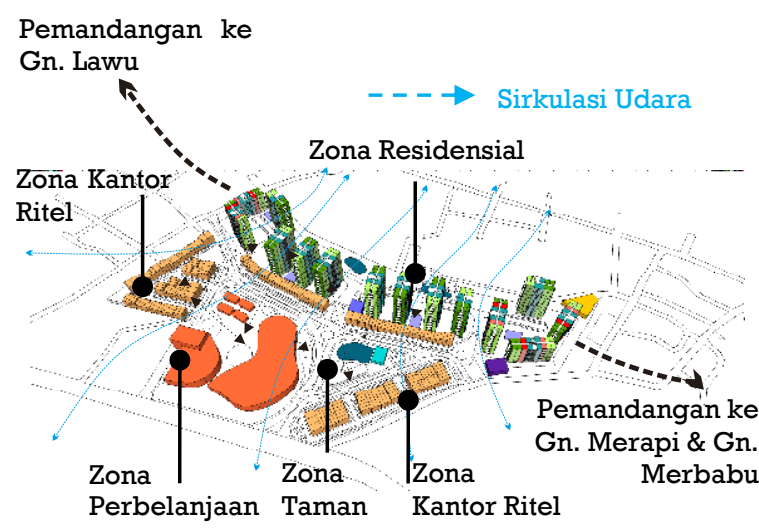

Gambar 1. Prinsip Tata Massa Kawasan Terpadu.

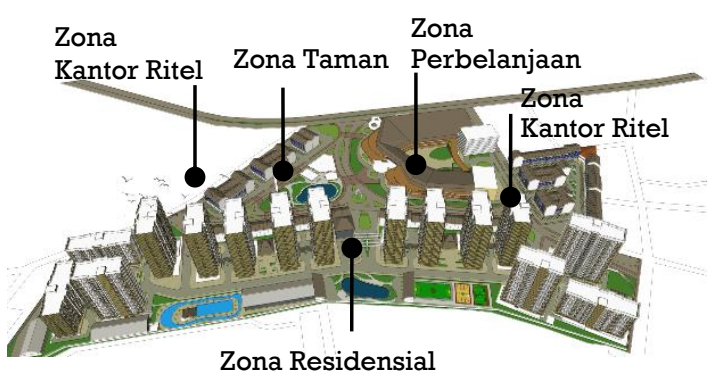

Gambar 2. Hasil Tata Massa Kawasan Terpadu.

Prinsip tata massa dalam perancangan kawasan terpadu menyesuaikan karakter dan fungsi setiap bangunan. Setiap zona ditata agar terjalin hubungan antar zona secara langsung sehingga masing-masing fungsi zona dapat saling mendukung. Bangunanbangunan di setiap zona juga memiliki arah hadap yang saling berhadapan sehingga mendukung potensi komersial kawasan terpadu.

Bangunan apartemen bertingkat tinggi ditata di bagian utara zona 
residensial, sedangkan yang bertingkat rendah dapat diposisikan di bagian pintu gerbang masuk zona komplek residensial dan pintu masuk kawasan terpadu sehingga pengguna yang masuk dapat merasakan skala bangunan yang menerus dan menyambut.

Bangunan apartemen yang tinggi dapat membentuk visual yang terlalu padat, khususnya bagi kawasan pemukiman dan perumahan sekitar tapak. Bangunan-bangunan apartemen dapat diarahkan berselang-seling dan bagian memanjang bangunan tidak diarahkan langsung ke arah pemukiman dan perumahan di sekitar tapak.

Posisi bangunan apartemen melintang menghadap barat dan timur agar pandangan pengguna kawasan terpadu maupun lingkungan sekitar tidak begitu terhalang padatnya bangunan. Selain itu, arah barat dan timur memungkinkan pemandangan ke berbagai obyek. Pemandangan ke arah barat dapat melihat gunung Merapi dan Merbabu, sedangkan ke arah timur dapat melihat gunung Lawu. Pemandangan menuju ke berbagai obyek ini dapat meningkatkan kualitas ruang di setiap unit apartemen.

Arah angin juga dipertimbangkan agar setiap zona memiliki kualitas udara yang baik dan mengalir. Bangunan apartemen yang lebar dan tinggi ditata demikian agar udara mudah bergerak ke setiap zona dan membentuk visual kawasan terpadu yang tidak terlalu masif walaupun terdapat banyak bangunan.

Kantor ritel dirancang menghadap ke semua sirkulasi utama dan jalan-jalan yang membatasi kawasan terpadu dan memanfaatkan arah hadap dari pusatpusat keramaian seperti zona taman dan zona area perbelanjaan berupa shopping mall untuk meningkatkan potensi bisnis kantor ritel.

Bangunan shopping mall diposisikan langsung berhadapan dengan Jalan Ringroad dan jalan sirkulasi utama kawasan terpadu sebagai fungsi penyambut sehingga dapat menarik perhatian pengunjung.

\subsection{Penerapan Prinsip Efficient Vehicular Circulation}

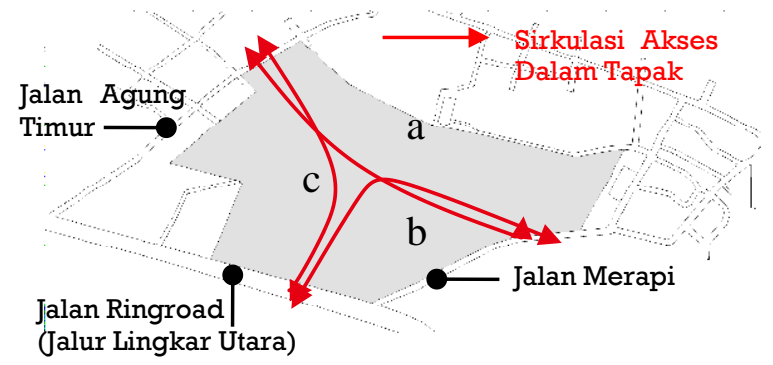

Gambar 1. Penataan Sirkulasi Kendaraan.

Sirkulasi di dalam kawasan terpadu dapat diarahkan memiliki sirkulasi yang menerus dan melewati semua fasilitas. Jalur kendaraan, jalur lambat, dan pejalan kaki dapat dipisahkan namun saling terintegrasi dengan semua fasilitas kawasan terpadu. Akses di dalam tiap zona juga harus mengarahkan pengguna secara menerus dari satu bangunan ke bangunan lainnya. Hal ini untuk menguntungkan zona-zona komersial yang membutuhkan kemudahan akses bagi pengguna dan pengunjung. Jalur sirkulasi dibuat aksesibel dan terbuka agar tercapai aspek kenyamanan dan keamanan pengguna.

Prinsip tata sirkulasi kendaraan diterapkan dengan menyesuaikan tatanan zona fungsi. Zona tapak dibagi dengan menarik sirkulasi yang menerus dari/menuju semua jalan yang mengililingi tapak. Jalan masuk utama dari Jalan Ringroad karena merupakan jalan utama. Area (a) jauh dari Jalan Ringroad yang ramai dan cenderung berkebisingan tinggi. Area (b) dan (c) merupakan area yang dekat dengan sirkulasi pengguna jalan sehingga dapat terlihat dan memiliki potensi komersial yang menguntungkan. Akses dari atau menuju apartemen

Efisiensi pola sirkulasi kendaraan diperlukan untuk mengurangi aktivitas berkendara di dalam kawasan terpadu. Semua fasilitas dapat mudah dicapai. 


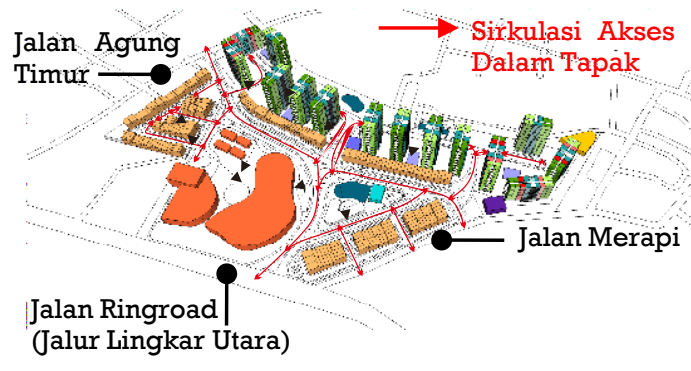

Gambar 2. Prinsip Penataan Sirkulasi Kendaraan Kawasan Terpadu.

Akses pencapaian utama menuju/dari kawasan terpadu diarahkan dari Jalan Ringroad untuk lebih menarik pengguna jalan dari berbagai arah dan memudahkan pengguna dan penghuni kawasan terpadu dalam mengakses jalan arteri.

Akses pencapaian sekunder menuju/dari kawasan terpadu diarahkan dari Jalan Merapi dan Jalan Agung Timur karena dapat menghubungkan tapak dengan pengguna dari Sumbing Raya maupun Jalan Ringroad. Jalan Merapi dapat menghubungkan tapak dengan dengan masyarakat dari arah barat tapak. Jalan Agung Timur dapat menghubungkan tapak dengan masyarakat dari arah timur tapak.

Sirkulasi dalam tapak diarahkan dapat mencapai dan menghubungkan semua bangunan dalam kawasan terpadu sehingga tetap mendukung efisiensi sirkulasi pengguna skawasan terpadu. Pengguna kawasan terpadu cukup berjalan kaki dan dapat mencapai semua fasilitas dengan mudah dari semua jalan di dalam ataupun di sekitar superblok.

Sistem parkir basement menerapkan sistem komunal untuk mengefisienkan luasan parkir. Basement antar bangunan dihubungkan untuk mendapatkan luasan yang cukup bagi kebutuhan pengguna apartemen. Semua kendaraan diwadahi di dalam basement untuk mengurangi jumlah parkir pinggir jalan.

\subsection{Penerapan Prinsip Multilayers Pedestrian Linkage}
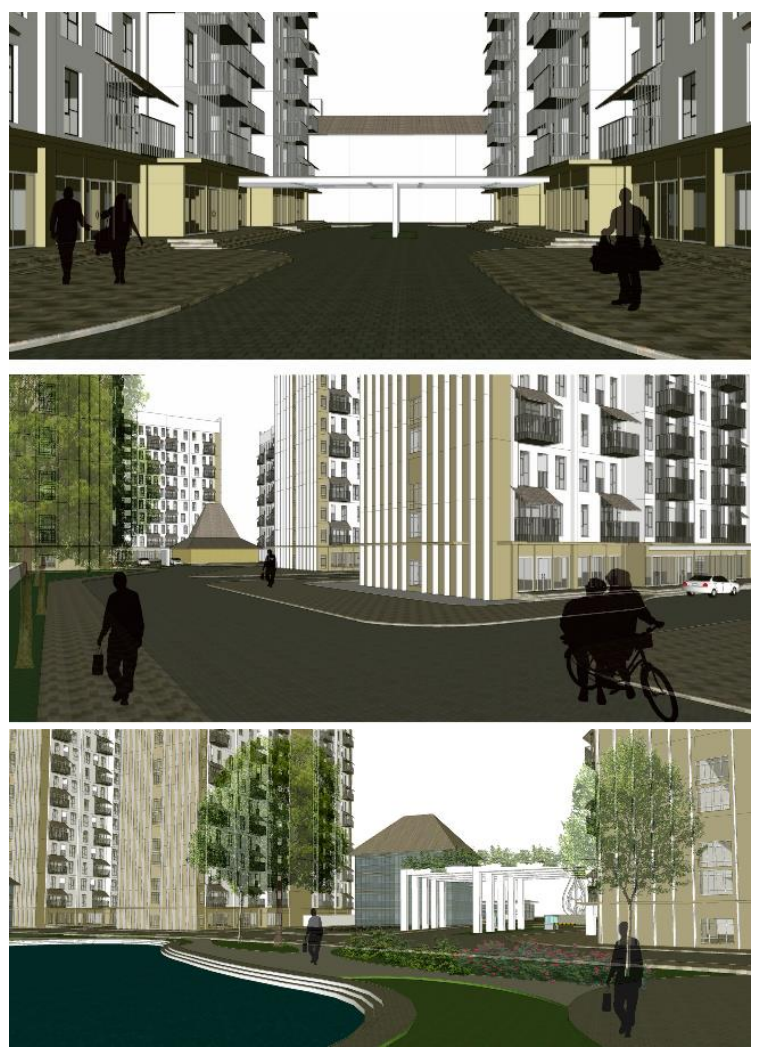

Gambar 1. Prinsip Sistem Pedestrian Kawasan Terpadu.

Akses pejalan kaki membutuhkan sirkulasi yang dekat dengan semua fasilitas kawasan terpadu. Jalur pejalan kaki harus mendapat perhatian utama untuk mendorong pengguna mengakses semua fasilitas dengan hanya berjalan kaki. Kebutuhan akan sirkulasi yang efisien dan nyaman di area pedestrian membutuhkan akses yang menerus dan terhubung dengan segala fasilitas yang dibutuhkan pengguna.

Prinsip kenyamanan pedestrian diterapkan dengan memberikan fasilitas pedestrian di setiap sisi. Pedestrian dibuat di sekeliling zona bangunan dan sisi jalan sehingga pengguna kawasan terpadu dapat mencapai semua bangunan lebih mudah dan terintegrasi. Pedestrian dihadirkan dengan memberi ketinggian sepuluh sentimeter $(10 \mathrm{~m})$ agar tidak terlalu tinggi dari jalan. Pedestrian juga dibuat selebar tiga meter 
(3 m) untuk memberi luasan yang nyaman bagi berbagai aktivitas dan moda mobilisasi pengguna kawasan terpadu seperti jalan kaki dan menggunakan kursi roda.

Suasana pedestrian dibuat lebih alami. Penggunan material batu alam dan batas pedestrian berupa pepohonan dan perdu membuat pengguna kawasan terpadu lebih betah saat berjalan kaki. Tumbuhan yang dipakai di jalur sirkulasi memakai pohon-pohon dengan luas daerah bayangan yang cukup besar agar suhu pedestrian lebih sejuk dan dapat menjadi elemen yang menerus sebagai pengarah sirkulasi pedestrian. Penggunaan elemen alam demi kenyamanan berjalan kaki berguna mendorong berkurangnya penggunaan kendaraan pribadi dan membentuk kualitas udara kawasan terpadu yang lebih baik.

\section{KESIMPULAN}

Sistem keterpaduan di dalam konsep superblok dapat menjadi salah satu solusi dalam menyelesaikan masalah perkotaan. Kota harus memiliki sistem yang komprehensif dalam menyikapi peningkatan jumlah penduduk dan hunian. Lima prinsip dalam konsep superblok dapat menjadi salah satu solusi dalam mewadahi hunian dalam jumlah besar sekaligus terkonseksi dengan berbagai fasilitas.

Kota Surakarta dengan berbagai masalah dan potensi kota yang dimiliki dapat mengadaptasi konsep superblok. Pemenuhan kekurangan hunian (backlog) dapat diusahakan dengan konsep ini. Lima prinsip dalam konsep superblok dapat membentuk suatu kawasan terpadu untuk fungsi hunian yang terintegrasi dan tersistem dengan fungsi-fungsi penunjang kehidupan pengguna.

Kawasan terpadu di Jalur Lingkar Utara Kota Surakarta dirancang dengan menerapkan lima prinsip utama dalam konsep superblok antara lain:

\subsection{Prinsip Identity/Branding}

Diterapkan dalam elemen kelokalan berupa turunan bentuk atap tradisional Jawa berupa atap perisai dan limasan, selain itu ada pula pendopo-pendopo sebagai area publik.

\subsection{Prinsip Mix of Uses}

Diterapkan dengan menghadirkan tiga zona fungsi utama dalam kawasan terpadu berupa zona residensial (apartemen), zona perkantoran (kantor ritel), dan zona area perbelanjaan (shopping mall).

\subsection{Prinsip Massing Framework}

Diterapkan dalam penataan bangunan berdasarkan bentuk dan fungsinya. Bangunan apartemen yang tinggi ditata di belakang dengan posisi melintang menghadap barat dan timur sebagai latar kawasan terpadu, mempermudah sirkulasi udara, mengurangi efek padat, dan memungkinkan penghuni menghadap pemandangan. Sedangkan untuk fungsi komersial ditata di sepanjang sirkulasi utama tapak dan di depan tapak sebagai penyambut pengguna dan penarik pengunjung.

\subsection{Prinsip Efficient Vehicular Circulation}

Diterapkan dalam penataan sirkulasi kendaraan yang menghubungkan tapak dengan jalan sekitar dan menghubungkan antar bangunan di dalam tapak.

\subsection{Prinsip Multilayers Pedestrian Linkage}

Diterapkan dengan menghadirkan pedestrian yang nyaman, aksesibel ke berbagai bangunan, aman, dan dekat dengan alam.

Penerapan konsep superblok dalam rancangan kawasan terpadu di Jalur Lingkar Utara Kota Surakarta diharapkan dapat menjadi salah satu solusi yang lebih efisien dan terkonsep atas berbagai masalah perkotaan di Kota Surakarta. 


\section{REFERENSI}

Badan Pusat Statistik (BPS) Kota Surakarta. Kota Surakarta Dalam Angka Tahun 2014.

PERDA Kota Surakarta Nomor 1 Tahun 2012 Tentang Rencana Tata Ruang Wilayah Kota Surakarta Tahun 20112031.

PERDA Kota Surakarta Nomor 8 Tahun 2009. Tentang Bangunan

Ronald. (2012). Proses Merancang Perkantoran Di Mega Kuningan. Universitas Pelita Harapan

Suwirna. (2016). Kompleks Komersial Dan Hunian Terpadu Di Badung, Bali. Juruan Arsitektur Fakultas Teknik Universitas Udayana

Yanuar. (2014). Apartemen Dan Kantor Sewa Di Kabupaten Sleman Dengan Tata Ruang Dalam Dan Luar Yang Ramah Lingkungan Melalui Pendekatan Arsitektur Hijau. Program Studi Arsitektur Universitas Atma Jaya Yogyakarta 